\title{
道路関連情報の流通のための 位置参照方式に関する研究
}

\author{
今井 龍一 1 - 中條 覚 2 -松山 満昭 $3 \cdot$ 重高 浩一 1 - 石田 稔 4 - 浜田 隆彦 5 \\ 1正会員 国土交通省 国土技術政策総合研究所 高度情報化研究センター 情報基盤研究室 \\ ( (305-0804 茨城県つくば市旭1番地) \\ E-mail: imai-r92ta@nilim.go.jp, shigetaka-k258@nilim.go.jp \\ 2正会員 株式会社三菱総合研究所社会公共マネジメント研究本部 \\ （干100-8141 東京都千代田区永田町二丁目10-3） \\ E-mail: snakajo@mri.co.jp \\ 3非会員 朝日航洋株式会社 空間情報事業本部 計測・コンサルタント部 ITSグループ \\ （三350-1165 埼玉県川越市南台三丁目1-1） \\ E-mail: mitsuaki-matsuyama@aeroasahi.co.jp \\ 4非会員 一般財団法人日本デジタル道路地図協会 企画調查部 \\ （†102-0093 東京都千代田区平河町一丁目3-13） \\ E-mail: mishida@drm.or.jp
}

\begin{abstract}
5非会員＼cjkstart非特定営利活動法人ITS Japan 道路情報基盤活用委員会（†105-0011 東京都港区芝公園2-6-8）
E-mail: TAKAHIKO_HAMADA@denso.co.jp
\end{abstract}

\begin{abstract}
ICTやITSの進展に伴い, 渋滞, 災害, 規制や交通量などの多様な道路関連情報が地図上の位置と関連づ けて表現されている．多様な道路関連情報が組織や分野横断的に流通し，組み合わせることができれば， 既存の情報提供サービスの高度化や新たなサービスを実現できる. しかし，道路関連情報の交換に送り手 の持つ地図の経緯度を用いると, 受け手の地図上で異なる位置を示寸可能性がある.また, 既存の道路地 図が持つネットワークを用いると，道路の新設や拡幅などに伴うリンクIDやノードIDの経年変化の影響を 受ける課題を抱えている.

本研究は，道路の区間と参照点とを用いて相対的に道路上の位置を特定し，異なる地図間でも送信者の 意図する位置表現で道路関連情報が交換できる位置参照方式となる “道路の区間ID方式”を考案した。 そ して，同方式に準じた約20万 $\mathrm{km}$ の道路の区間IDテーブルを整備し，さらに情報交換実験を実施して有用性 を検証した。
\end{abstract}

Key Words : location referencing, road information provision, road network, digital road map, road section identification data set (RSIDs), intelligent transport systems

\section{1. 序論}

ICTやITSの革新により，道路分野でも多様な電子情報 が蓄積・交換されている.このうち, 渋滞, 災害, 規制, プローブデータや道路交通センサスなどの多くの道路関 連情報は，地図上の位置と関連づけて表現されている. このような多様な道路関連情報が既存の枠組みを越えて, 組織や分野横断的に流通し，組み合わせること（マッシ ユアップ）ができれば，既存の情報提供サービスの高度 化や新たなサービスを実現できる，また，こうしたサー ビスで提供する情報を受け取る端末は，カーナビゲーシ
ヨン, PND (Personal Navigation Device) やスマートフォン・ 携帯電話など, 多様化している. 地理空間情報を巡るビ ジネスや市場規模の切り口から分析された資料によると, カーナビゲーションの市場規模は約1兆円, 携帯端末の市 場規模は約9,700億円，インターネット利用の市場規模は 約800億円と示された1)ほか, 各種端末出荷台数は増加の 傾向にある2).これら社会動向や既往研究2)からも地図上 に表現された道路関連情報の流通は，産学官共通の二ー ズであると言える.

しかし, 地図上の位置と関連づけて表現された道路関 連情報の交換は，大別して2つの課題を抱えている3). ひ 
とつめは，情報の送り手の持つ地図の経緯度を用いて情 報交換すると，受け手の地図上で異なる位置を示寸可能 性がある課題である. この課題は, 各組織で保有寸る地 図の縮尺や精度が異なることが起因している.

ふたつめは, 既存の道路地図が持つネットワーク

(DRM : Digital Road MapやVICS : Vehicle Information and Communication System）のIDを基にした情報交換は経年変 化の影響を受ける課題である.この課題は，道路の新設 や拡幅などの変化に伴い，道路地図の持つネットワーク を構成するノードおよびリンクのIDの更新も経年変化す る運用になっていることが起因している.

一方，地図上の位置と関連づけた情報交換方法の海外 の動向としては, ITS分野の位置参照方式 (ISO 17572) ${ }^{406}$ や地理情報分野の線形参照 (ISO 19148) 》の国際規格があ る. ISO 17572では，情報提供者および情報受取者の双方 が共通のIDを用いて互いの地図（データベース）上の位 置を表現する概念が示されているが，具体的な方法は示 されていない，ISO19148では，線形地物上の位置の表現 方法が定められているが，線形地物のIDの定義方法は示 されていない.

既往研究に着目寸ると, 情報提供者側で道路形状や交 差点などの地物の位置参照に必要な情報（経緯度および 補足的な識別子）を生成して送信し，情報受取者側で当 該地物を探索する位置参照の方法が採用されている ${ }^{813)}$. しかし, 前述のひとつめの経緯度の課題から確実な位置 参照を実現していない. 一方，IDを用いた位置参照に着 眼し，上述の $2 つ の$ 課題に取り組んだ既往研究としては,

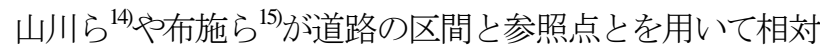
的に道路上の位置を特定し，異なる地図間でも送信者の 意図寸る位置表現で道路関連情報が交換できる方式（以 下，「道路の区間ID方式」という。）を提案している. しかし，これらの既往研究は机上検討で相対的な位置の 参照方法を構想した段階であり，今後の課題が残されて いる. 具体的には, 既存の道路地図との親和性を確保し た道路の区間 $\mathrm{D}$ 方式を実現させる仕様の作成，仕様に則 した位置参照テーブル（以下，「道路の区間IDテーブル」 という。）の整備や同方式の有用性の立証である.

本研究の目的は，国際規格に準拠した道路の区間ID方 式を実用化し，既存の情報提供サービスの高度化や新た なサービスの創出の実現とした．そのために，まず，道 路の区間ID方式の方法論を確立し, 仕様を具体化する. そして, 同仕様に準じた道路の区間Iテーブルを整備し， さらに実証実験を実施して有用性を検証する.

本論文の構成として, 2章にて道路の区間 $\mathrm{ID}$ 方式への要 件，3章にて道路の区間 $\mathrm{D}$ 方式の仕様を定義する．4章は 道路の区間IDテーブルの整備内容，5章は道路の区間 $\mathrm{DD}$ 方式の有用性の検証結果，そして6章で結論を論ずる.

\section{2. 道路の区間ID方式の要件定義}

\section{(1) 道路の区間ID方式の概念}

道路の区間ID方式は，道路の区間と参照点とに恒久的 なIDを付与し，区間と参照点および参照点からの道程を 元に位置を表現する（図-1参照）。この結果，図-2のよ うに，道路との相対位置関係を各機関で齗踣無く共有で きるようになり，前章で述べた2つの課題を解決する.

\section{（2）要件定義}

既往研究では, 道路の区間ID方式に対する8つの要件が 定義されている3). 本研究は, 事業関係者 (道路管理者, カーナビ地図メーカ, カーナビメーカや自動車メーカ) と議論して各要件を再考した. その結果,「IDが意味を もつこと」および「道案内に使いやすいこと」の2つの要 件は，道路の区間IDテーブルに収録する属性の定義の仕 方で満足できることから，次の6つの要件に再定義した.

1)道路を基準とした相対的位置関係が表現できること.

2)距離標で管理されるデータが容易に扱えること.

3）ID付番ルールが明確であり，どのような道路にも適 用可能であること.

4)情報交換に伴うデータサイズが軽量であること.

5) 道路網や道路構造の変更による経年変化へ対応でき ること.

6)道路の区間 IDテーブル更新の労力が少ないこと.

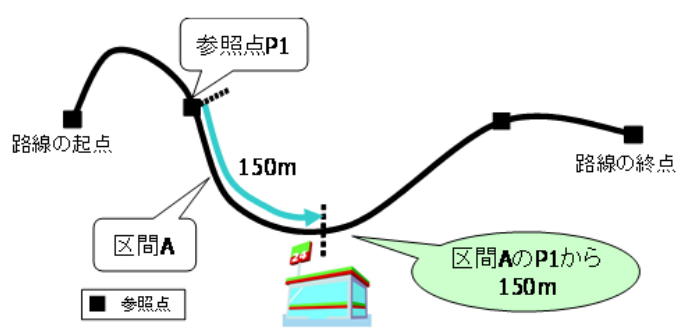

図-1 道路の区間 $\mathrm{ID}$ 方式の概念

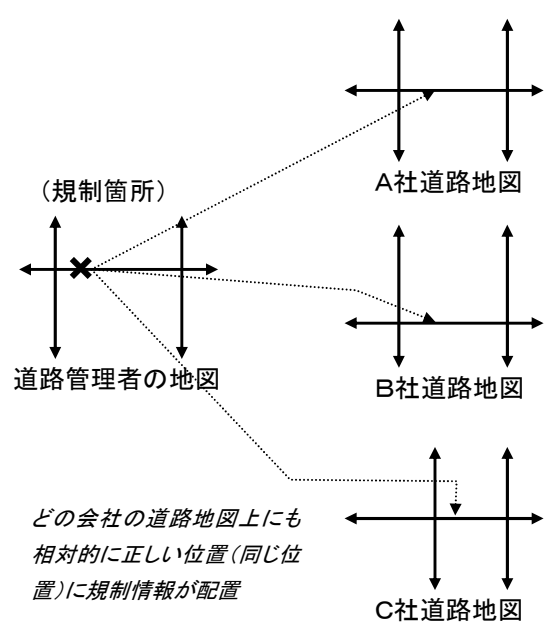

図-2 道路の区間 $\mathrm{D}$ 方式による位置情報の共有 


\section{3. 道路の区間ID方式の仕様の定義}

本研究は，道路の区間ID方式への要件を満足する仕様 を以下のとおり定義した。

\section{(1) 区間}

区間は，道路の起終点，都道府県道以上の交差点およ び県境で区切られる2点間毎に一つの単位とした. 道路の 起終点は，都道府県道以上との交差点または県境でない 場合も参照点を設定の上，区間の端点とする。図-3のよ うな場合，区間の端点となる参照点は，県境と都道府県 道と交差する点に設定される。したがって，A，Bおよび Cの3つの区間となる.

\section{(2) 参照点}

参照点は，区間の端点とそれ以外の経由点として，代 表的な交差点, 距離標, 市区町村境およびその他道路管 理者が定める点とした，したがって，参照点は，区間の 端点として用いる点と経由点として用いる点からなり， 表-1に示す5種類とした.

\section{(3) IDの付与}

区間および参照点は(5)に示す手順で設定し，それぞれ 区別してIDを付与する. 区間IDおよび参照点IDは，半角 英数字の11桁で表現する (図-4参照). はじめの6杕には, JIS X 04107の地域メッシュコードに準拠したエリアコー ドを付与する. 残りの5桁には, 各エリアコード内で重複 のないシーケンシャルIDを付与する。一度付与した区間 IDおよび参照点IDは恒久の扱いとし, 再付与 (再付番) しない規定とした.

\section{（4） 区間・参照点の属性}

道路の区間IDテーブルは，区間テーブルおよび参照点 テーブルから構成し，それぞれのIDを補足する属性值を

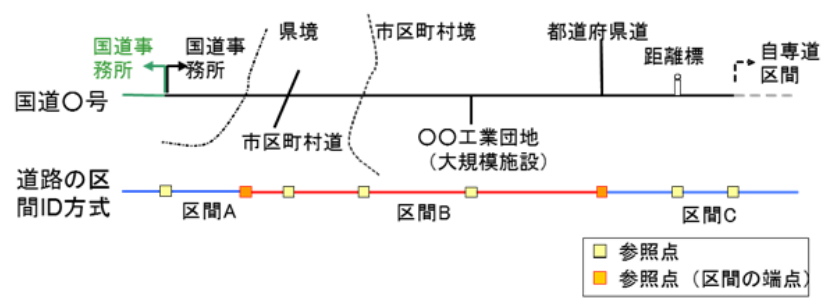

図-3 区間の設定例

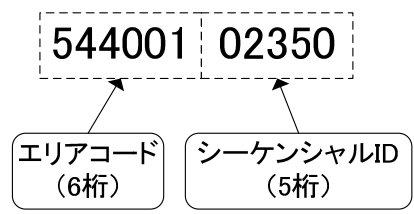

図-4 区間ID及び参照点 $\mathrm{D}$ の表現方法
持つ仕様とした，属性は，表-2に示すとおり，区間およ び参照点それぞれに対して，a)当該 $D$ D場所特定に必要 な属性，b)道路の区間IDテーブル生成時に使用したDRM との対応を示寸属性を定義した. また, 要件4)～6)に対応 するため, リンク長や起点からの距離の属性は参考值の 扱いとし，道路の形状や接続関係を示寸属性は保持しな い規定とした。

\section{(5) 道路の区間IDテーブルの整備方法}

道路の区間 $\mathrm{D}$ テーブルは，区間および参照点から構成

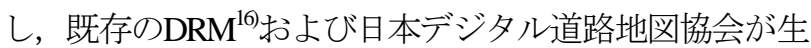
成するペアリンクデータ（二条の道路におけるリンクや 交差点のペアを定義したリスト）を用いて作成する，具 体的な整備手順を図-5に示す．まず，DRMにペアリンク データを適用し，道路を一条化する，その上で，整備対 象の道路（DRM）リンクを抽出する. 次に，参照点とし て，区間の端点を設定し，さらに表-1に準じて経由点を 設定する．最後に，設定した区間および参照点のそれぞ れを区別してIDを付与し，DRMなどを参照して各属性を 定義する．図-6は具体例を示しており，二条化している 道路や交差点は抽象化するなど，道路の概念としてのひ とまとまりのセグメントや基準となる箇所に参照点を付 与している.

表-1 参照点の種類

\begin{tabular}{|c|c|c|c|}
\hline & \multirow{2}{*}{ 参照点の種類 } & \multicolumn{2}{|c|}{ 区間上の取扱い } \\
\hline & & 端点 & 経由点 \\
\hline \multirow{2}{*}{ 交差点 } & 立体交差·JCT·IC部 & $(\bigcirc){ }^{2}{ }^{1}$ & $(\bigcirc)^{*^{2}}$ \\
\hline & 上記以外の交差点 & $(\bigcirc) * 1$ & $(\bigcirc)^{* 2}$ \\
\hline \multicolumn{2}{|l|}{ 距離標 } & & 0 \\
\hline \multicolumn{2}{|l|}{ 県境 } & 0 & \\
\hline \multicolumn{2}{|c|}{ 市区町村境 } & & 0 \\
\hline \multicolumn{2}{|c|}{$\begin{array}{l}\text { その他道路管理者が定める点 } \\
\text { （道路管理者が異なる箇所, 自動車専用 } \\
\text { 道路に指定されている区間の起終点, } \\
\text { 大規模施設などへのアクセス点） }\end{array}$} & & 0 \\
\hline
\end{tabular}

$※ 2$ : 区間の間に県道以上の交差点が設置されても端点にはならない.

表-2 区間および参照点の属性

\begin{tabular}{|c|c|c|}
\hline 要素 & 属性区分 & 属性 \\
\hline \multirow[t]{2}{*}{$\begin{array}{l}\text { 区 } \\
\text { 間 }\end{array}$} & a)場所特定に必要な属性 & $\begin{array}{l}\text { 区間ID, 起点参照点ID, 起点距離標 } \\
\text { 値, 終点参照点ID, 終点距離標値, } \\
\text { リンク長, 道路種別コード, 参照点数 } \\
\text { (参照点ID, 起点からの距離), 路線 } \\
\text { 総数(主道路判別フラクク, 区間起点 } \\
\text { 参照点ID, 区間終点参照点ID, 路線 } \\
\text { コード, 路線名数 (路線名)), 属性の } \\
\text { 更新白 }\end{array}$ \\
\hline & $\begin{array}{l}\text { b)IDテーブル生成時に使用し } \\
\text { たDRMとの対応を示寸属性 }\end{array}$ & $\begin{array}{l}\text { 区間ID, DRMバージョン番号, 対応 } \\
\text { DRMリンク数 (2次メッシシード, 基 } \\
\text { 本道路リンク番号), 属性の更新日 }\end{array}$ \\
\hline \multirow{2}{*}{$\begin{array}{l}\text { 参 } \\
\text { 照 } \\
\text { 点 }\end{array}$} & a)場所特定に必要な属性 & $\begin{array}{l}\text { 参照点ID, 緯度, 経度, 種別コード, } \\
\text { 参照点名称, 距離標数 ( 区間ID, 距 } \\
\text { 離標値), 属性の更新日 }\end{array}$ \\
\hline & $\begin{array}{l}\text { b)IDテーブル生成時に使用し } \\
\text { たDRMとの対応を示寸属性 }\end{array}$ & $\begin{array}{l}\text { 参照点ID, DRMバージョン番号, 対 } \\
\text { 応DRMノード数 (2次メシシュコード, } \\
\text { 基本道路ノード番号), 属性の更新日 }\end{array}$ \\
\hline
\end{tabular}




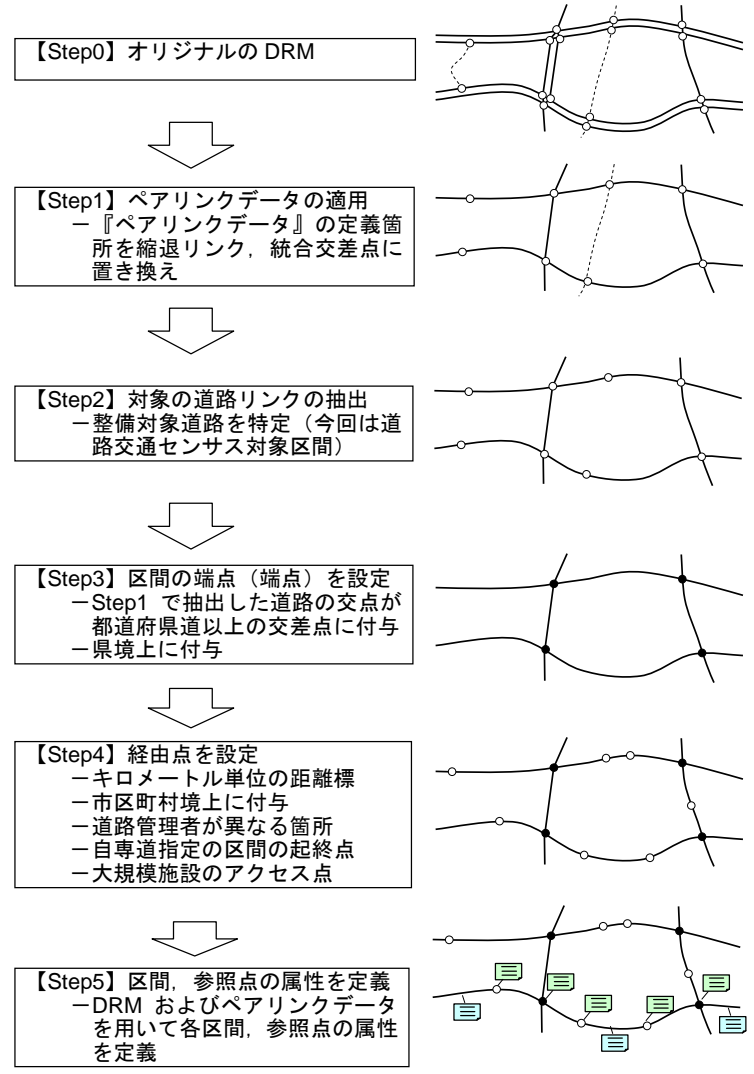

図-5＼cjkstart道路の区間Iテーブルの整備手順
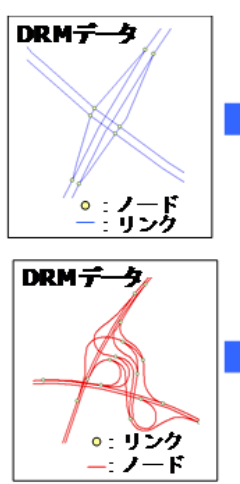

図-6
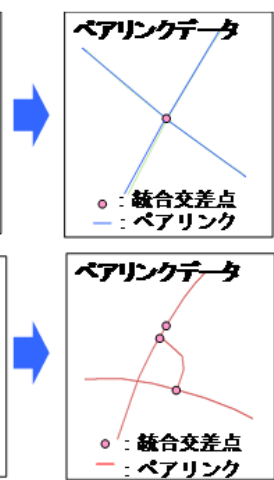

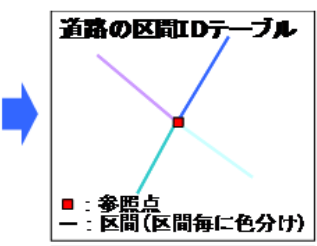

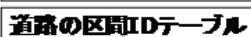

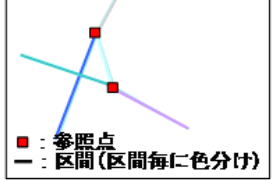

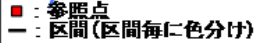

区間および参照点の設定方法

\section{(6) 道路の区間IDテーブルの更新方法}

道路網や道路構造は経年変化することから，道路の区 間ID方式でも柔軟な更新方法を確立しておく必要がある. 既往研究 ${ }^{14-15)}$ の道路の変更区分の分析結果によると，道 路区間IDテーブルの区間および参照点のIDは経年変化せ ずに付与可能であると示唆されている.

本研究は, 既往研究の成果や実際に道路区間IDテーブ ルを作成（4章参照）して得た知見に基づいて，経年変化 により想定される区間や参照点の変化のパターンを抽出 し，各パターンに対し自動処理による区間および参照点 IDの更新が可能であるかを分析した．具体的には，(a)区 間の新設，(b)道路の線形形状および路線管理上の変更， (c)ペアリンクデータの変更の各パターンを分析した.
表-3 区間の新設における更新パターン

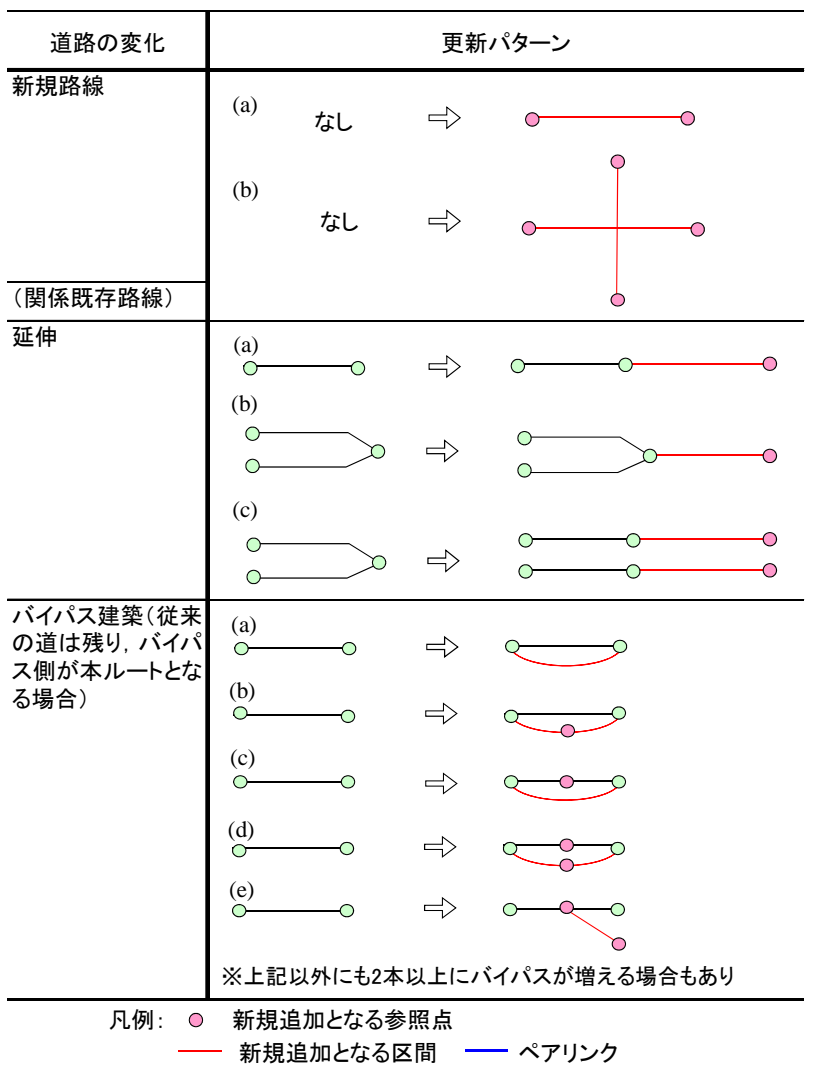

表-3は，区間の新設の場合のパターンである. 更新パ ターンの闌の左側が更新前, 矢印の右側が更新後を示し ている（後述の表-4および表-5も同様の見方である）。 区間の新設は，約89万kmの道路ネットワークが収録され ているDRMの新設内容の分析とともに, 本章(7)の試作結 果や第4章の道路交通センサスの対象路線 (全国の都道府

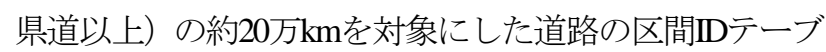
ルの整備結果を用いて分析し，表-3に示す計10パターン の結論を得た。また，年度別のDRMを用いて差分（道路 の新設箇所）を抽出し，その内容を分析した結果も表-3 に示す 10 パターンであることが明らかになった。このた め, 毎年更新されるDRMから新設箇所を対象にした道路 の区間IDテーブルの生成プログラムの実装が可能である ことが示唆できた。

表-4は，道路の線形改良および路線管理上の変更に関 する更新パターンである。この更新パターンも区間の新 設と同様に，DRM，本章(7)の試作結果および第4章の道 路の区間IIテーブルの整備結果を用いて分析した. また, 年度別のDRMを用いて差分（道路の線形改良および路線 管理上の変更箇所）を抽出し，その内容を分析した。こ の結果，表-4に示す14パターンを得た。これにより，毎 年更新されるDRMから道路の線形改良および路線管理上 の変更箇所を対象にした道路の区間 $\mathrm{ID}$ テブルの生成プ ログラムの実装が可能であることが示唆できた．また， 道路の経年変化としては, 路線や交差点の廃止および交 
表-4 道路の線形改良および路線管理上の変更の更新パターン

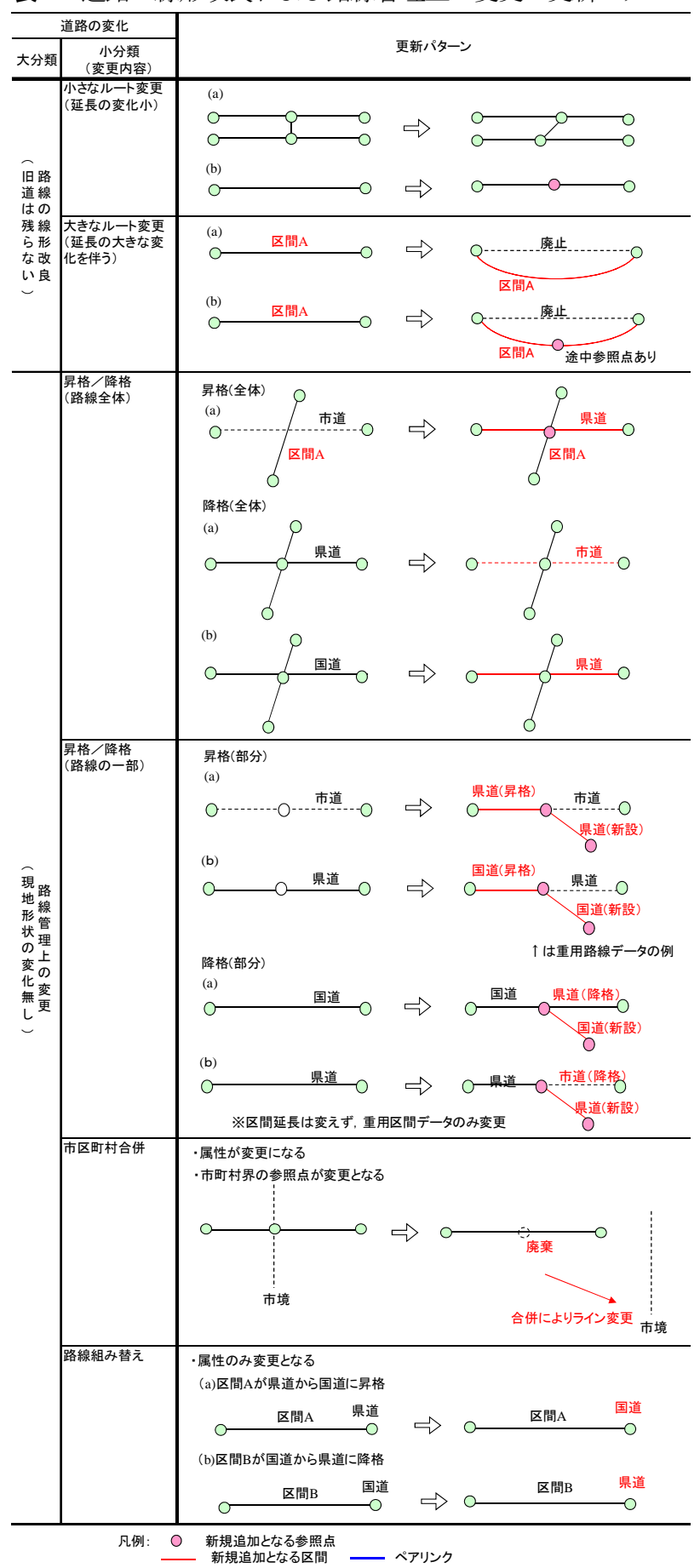

差点の名称変更も挙げられる. これらの扱いも同様に分 析した結果，路線や交差点の廃止の場合，道路の区間ID 方式はIDが恒久的なので，IDの変更は生じない．また， 交差点の名称変更は，IDの変更には影響を及ぼさないこ とを確認できた．したがって，新設は表-3，路線の線形 改良および路線管理上の変更は表-4, 路線や交差点の廃 止の場合は区間・参照点 $\mathrm{D}$ を永久欠番, 交差点の名称変 更の場合は参照点の属性（参照点名称）の変更にて経年 変化に一通り対応することができる.

表-5は, ペアリンクデータの変更に伴う更新パターン

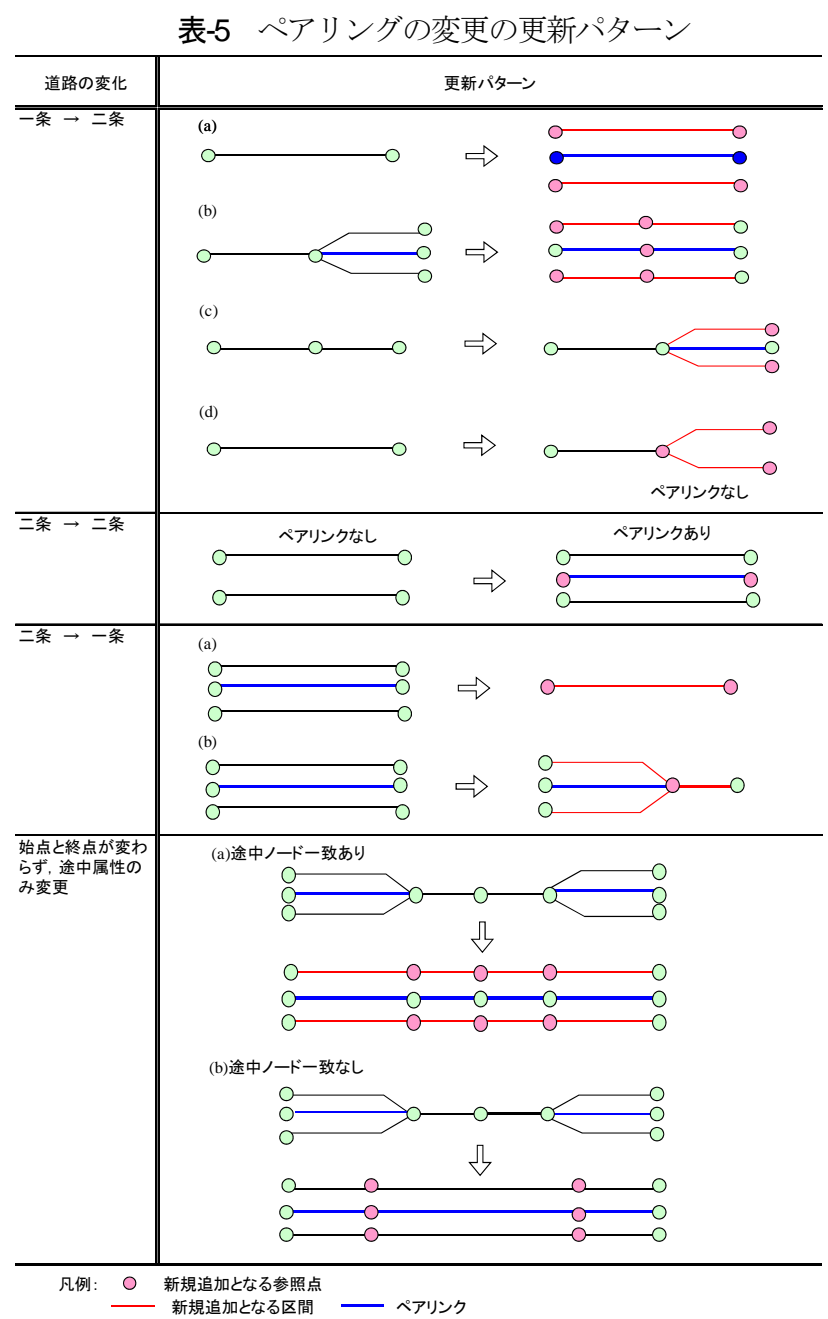

である.この更新パターンは, 年度別のDRMから抽出し た差分（道路の更新箇所）をペアリンクデータに適用し た結果を分析し，表-5に示寸計9パターンの結論を得た. この9パターンは, 第4章の道路の区間Iテテーブルの整備 の際にも確認できた. ペアリンクデータの変更は, ペア リンクデータと元のDRMの形状が大きく変わっていた場 合，プログラムによる自動処理では新たな区間の生成で あるかペアリンクデータの変更であるかの判別が難しい ケースが存在する可能性がある. したがって，完全な自 動処理で道路の区間Iテーブルを更新するには，ペアリ ンクデータの履歴管理などを定める必要があることが明 らかになった。

\section{（7）道路の区間IDテーブルの試作による検証}

本研究では, 前章で定義した仕様に則して道路の区間 IDテーブルを試作し，技術的な実現性を検証した。

\section{a) 検証の着眼点}

データ試作による検証は次の2点に着眼した.

1点目は，区間と参照点とを関連づけられるようにする ために，区間の属性には参照点IDを収録する規定として いるので，齟龆が生じていないかを確認する. 
2点目は, 道路の区間Iテテーブルの生成時に使用したデ 一タとの対応を示す属性の収録状況を過剰，不足および 重複の観点から確認する．具体的には，今回の試作には DRMを利用するため, 対象路線以外のDRMリンク番号が 区間の属性に格納されていないか（過剰），対象路線の DRMリンク番号が区間の属性から漏れていない(不足)， 対象路線のDRMリンク番号が複数区間の属性に格納され ていないか（重複）を確認する。 また，参照点の属性も 同様に，DRMのノード番号の収録状況を過剰，不足およ び重複の観点から確認する.

b) 対象エリア

道路の区間IDテーブルの試作の対象エリアは，次の条 件を満たす2次メッシュ544001（図-7の赤枠内）とその周 辺の県道以上の路線（図-7の赤丸を含む路線）とした.

・JCTやICのような道路線形が複雑な交差点を含む

・5種類の参照点（表-1参照）を含む

・二条道路を含む

\section{c) 試作結果}

道路の区間IDテーブルを試作した結果, 約100の区間と 約80の参照点を得た。図-8は，DRMデータと試作した道 路の区間IDテーブルの一例を示している. 図-8の上段を 見ると，筋違い交差点が参照点として適切に表現されて いる. 図-8の下段を見ると，JCTと他路線と接続する起点 に最も近い分合流部と終点に最も近い分合流点のおよそ 中心に生成された箇所が参照点として設定されている.

したがって，いずれも前章で定義した仕様に則して区間 と参照点とが生成できていることが確認できた.

前項a）で述べた検証の着眼点の2点は，試作したデー タのすべてを目視で確認した．1点目の確認結果として, 生成した区間と参照点のそれぞれに齟踣無く参照点のID 番号が収録されていた。また，2点目の確認結果として， 道路の区間IDテーブルの生成時に使用したDRMと区間お よび参照点との間で，過剰，不足および重複のいずれも 生じていなかった，以上の結果から，前章で定義した仕

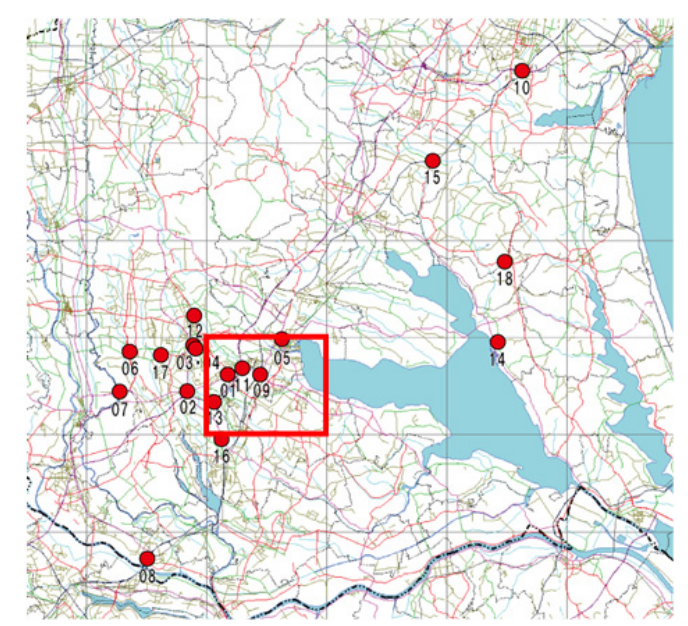

図-7 道路の区間IDテーブルの試作対象エリア
様に則した道路の区間IDテーブルの生成は，技術的に実 現可能であることがわかった.

\section{(8) 道路の区間 ID テーブル標準の作成}

これまでの仕様検討や道路の区間IDテーブル試作を踏 まえ，本研究は，我が国の道路を対象に道路の区間I方 式を適用することを目的として，共通基盤となる道路の 区間IDテーブルを定める「道路の区間IDテーブル標準」 を作成した，同標準の作成には，国際規格にも準拠する ことに留意した. 具体的には, ISO 17572におけるPre-coded

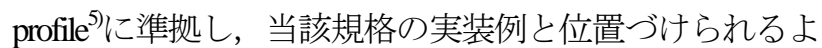
うにした。 また，位置表現の要素は，ISO191487の表現を 逸脱しないように定義した。

\section{（9） 既存の位置参照方式との比較}

本節は，既存の地図，道路ネットワークや位置参照方 式と，道路の区間ID方式との関係を整理し，同方式の位
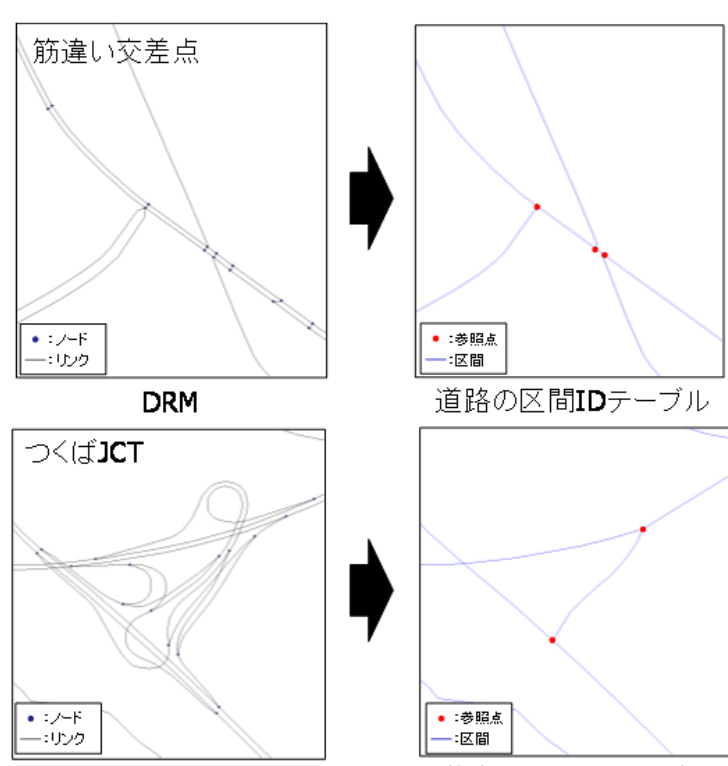

道路の区間IDテーブル

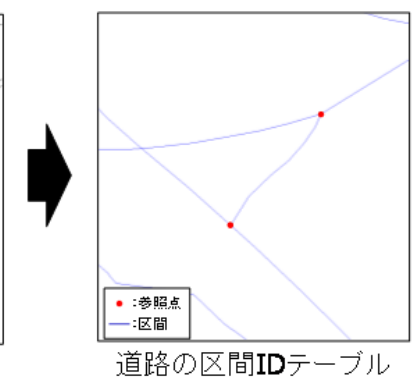

図-8 試作結果

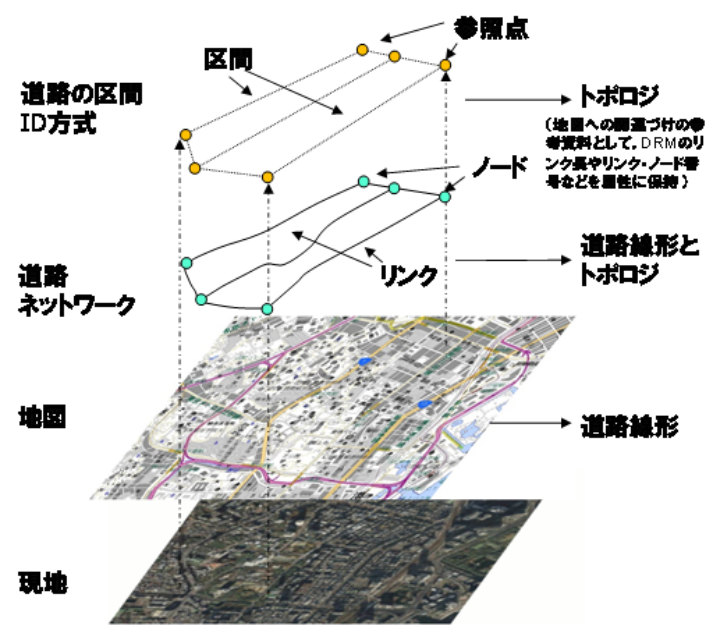

図-9 道路ネットワークと道路の区間 ID 方式との関係 
置づけを述べる．図-9は，既存の地図や道路ネットワー クと道路の区間ID方式との関係を示している，通常，地 図は，ポリゴン（座標，線種や描画ポイントを属性で保 持）およびポリライン（座標や線種を属性で保持）を用 いて道路の形状を表現している，すなわち，地図は道路 線形（直線・曲線による平面線形）を保持している.

道路ネットワークは，各機関で整備基準が定められて おり，原典と寸る地図から道路線形を保持して道路中心 線を抽出し，交差点などの結節点をノード（座標を属性 で保持）とし，ノードとノードとの間をリンク（起終点 ノードや形状点列座標を属性で保持）として道路の接続 関係を表現する. 寸なわち, 道路ネットワークは道路線 形とトポロジとを保持している.この結果, 経路の探索 や案内を行うことができる. しかし，各機関の整備基準 が異なるため, 道路ネットワークが保持する道路線形も 異なる. また，図-10のような交差点が整備されると，リ ンクが分割されてIDが再付番されるため，前章で述べた

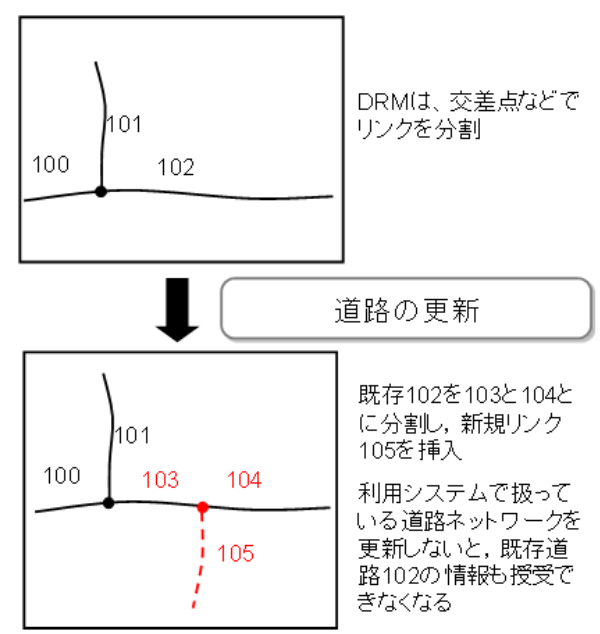

図-10 既存の道路ネットワークのDの更新方法
道路ネットワークの経年変化の影響が生じる.

一方，道路の区間ID方式はトポロジの保持を主眼にし ている．ただし，各機関保有の地図に道路の区間I $\mathrm{D}$ 一ー ブルを関連づける際の参考資料として，DRM（原典）に 収録されている道路のリンク長やリンク・ノード番号な どを属性として収録している（表-2）。表-6は，道路の 区間ID方式と既存のIDを用いた位置参照方式との比較結 果を示している. VICSや道路交通センサスは, リンクの みがID付与の対象である。一方，DRMはノードおよびリ ンクをIDの付与対象としているが，道路線形も保持して いる．また，既存のIDを用いた位置参照方式は，Iが経 年変化し，リンクの分割などにより同じ道路区間に対し 別のIDが付与されるのが一般的である（図-10参照）。

VICSなど一部の方式では対応テーブルを準備して運用上 の対処が行われているが，IDを経年変化させる点は他の 既存の位置参照方式と同じである.このため, 既存のID を用いた位置参照方式は, IDが経年変化することにより, 時系列分析が難しくなるなどの課題を抱えている.

図-11は, 道路構造の変化に伴う既存の道路ネットワー クおよび道路の区間ID方式の位置参照の遷移の一例を示 している．道路ネットワーク方式は，路線の追加や変化 の都度，ノードDやリンク $\mathrm{D} か ゙$ 更新されるのでDに経年 変化が生じる，道路の区間ID方式は，交差点を集約し，

表-6 道路の区間 ID 方式と既存方式との比較

\begin{tabular}{|c|c|c|c|c|}
\hline 特徵 & $\begin{array}{c}\text { 道路の区間ID } \\
\text { テーフフル }\end{array}$ & DRM & VICS & $\begin{array}{l}\text { 道路交通 } \\
\text { センサス }\end{array}$ \\
\hline ID付与対象 & 区間, 参照点 & ノード, リンク & リンク & リンク \\
\hline IDの経年変化 & \begin{tabular}{|l|} 
無 \\
\end{tabular} & \begin{tabular}{|l|} 
有 \\
(リンクを分割する \\
新設道路が整備さ \\
れた場合など)
\end{tabular} & \begin{tabular}{|l|} 
有 \\
(過去3時点(年) 分 \\
ळIはは保持)
\end{tabular} & $\begin{array}{l}\text { 有 } \\
\text { (道路交通調查毎 } \\
\text { に変化する場合が } \\
\text { ある) }\end{array}$ \\
\hline $\begin{array}{l}\text { 道路形状の表現 } \\
\text { (形状変化点の有無) }\end{array}$ & 無 & 有 & 無 & 無 \\
\hline
\end{tabular}

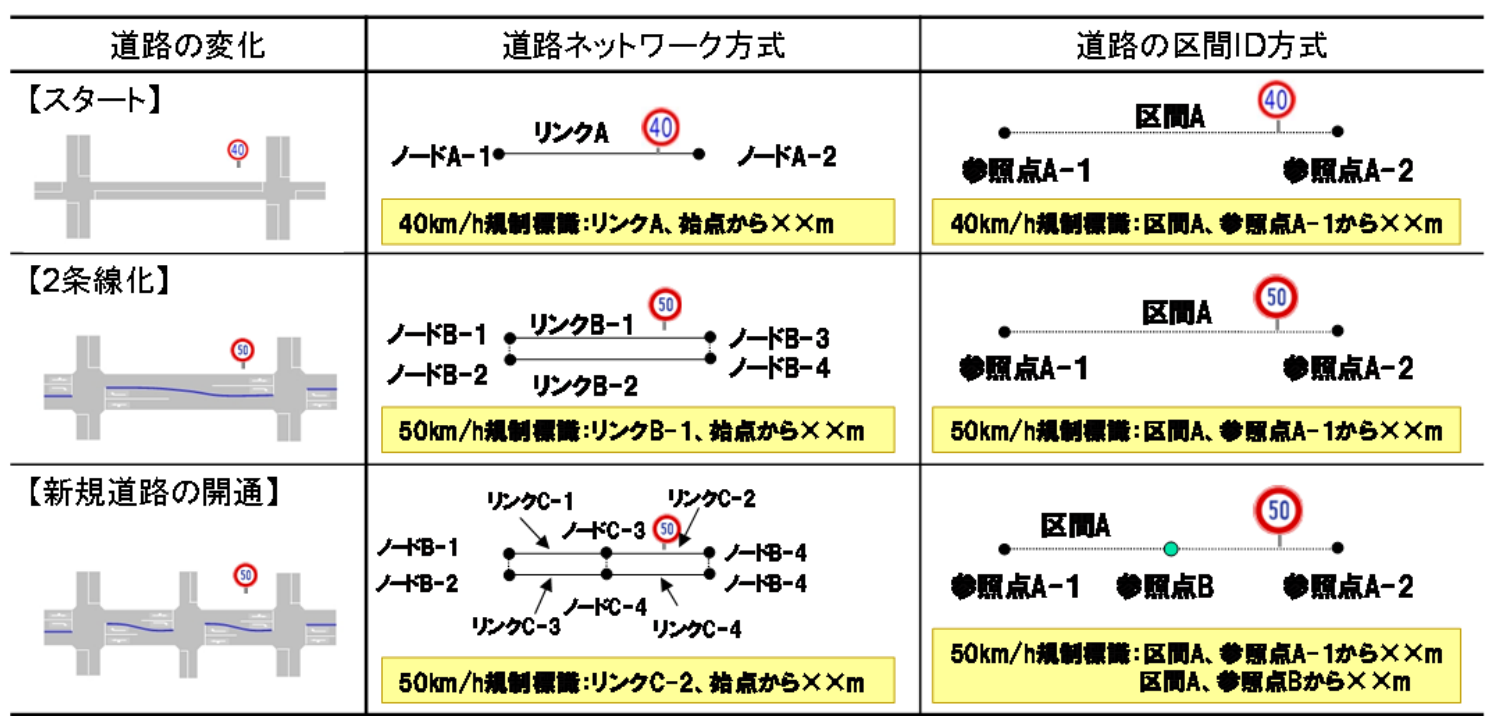

図-11 既存の道路ネットワークおよび道路の区間 ID 方式の位置参照の遷移 
一度付与したDを変更しない.このため, 路線の追加や 変化があっても参照点の対象である交差点の増設時に経

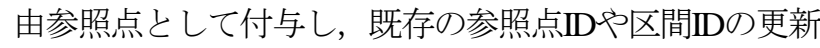
は無く経年変化が起こらない。

以上のことから，道路の区間ID方式は，既存の道路ネ ットワークとの親和性を確保しつつ, 地図上の位置と関 連づけた道路関連情報の交換における課題を解決する国 際規格に準拠した位置参照方式であると言える.

\section{4. 道路の区間IDテーブルの整備}

本研究は，前章で定義した標準に則して道路の区間 $\mathrm{D}$ テーブルを作成した．具体的には，主に都道府県道以上 の重要路線として扱われている道路交通センサス対象路 線 ${ }^{18)}$ の約20万 $\mathrm{km}$ を初期整備の対象とした. 表-7は整備し た道路の区間IDテーブルの概要である。データ量は約 $32 \mathrm{MB}$ ，区間数は約 9 万区間，参照点数は約 11 万点であっ

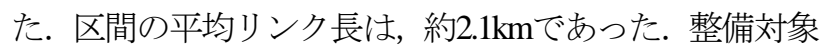
道路が異なるため，一概な比較はできないが，DRM基本 道路が整備延長約39万 $\mathrm{km}$ に対してリンク数が約131万で あり，区間数は大幅に減少している.

\section{5. 道路の区間ID方式の有用性の検証}

\section{(1) 実験計画}

道路の区間 $\mathrm{D}$ 方式を用いて道路関連情報を流通させる には，道路の区間IDテーブルと各機関保有の地図とを関 連づける必要がある. その後, 道路の区間ID方式に準じ て表現した道路関連情報を各機関で交換することになる.

前章で論じたとおり，本研究では，約20万kmの道路の 区間Iテーブルを作成した。しかし，現時点では上述の ような道路関連情報の流通への適用性や道路の区間 $\mathrm{D}$ 方 式の有用性の十分な検証ができていない.

このことを踏まえ，本研究は，道路の区間 $\mathrm{D}$ 方式の有 用性や実運用への適用性を明らかにするために必要とな

表-7 整備した道路区間IDテーブルの概要

\begin{tabular}{|c|c|c|c|c|c|c|}
\hline \multirow{2}{*}{ No } & \multirow{2}{*}{ 地域 } & \multicolumn{2}{|c|}{ データ量 } & \multirow{2}{*}{ 区間数 } & \multirow{2}{*}{ 参照点数 } & \multirow{2}{*}{$\begin{array}{c}\text { 区間の平均 } \\
\text { リンク長 } \\
(\mathrm{m})\end{array}$} \\
\hline & & 参照点(MB) & 区間 (MB) & & & \\
\hline $\begin{array}{ll}1 \\
\end{array}$ & 北海道 & 1.05 & 1.33 & \begin{tabular}{l|l|}
4327 \\
\end{tabular} & \begin{tabular}{|l|l|}
11,048 \\
\end{tabular} & 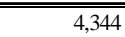 \\
\hline 2 & 東北 & 1.16 & 2.33 & \begin{tabular}{|l|l|}
9,213 \\
\end{tabular} & \begin{tabular}{|l|}
12,498 \\
\end{tabular} & 2,821 \\
\hline 3 & 北陸 & 0.67 & 1.62 & 6,862 & 7,246 & 1,822 \\
\hline 4 & 関東 & 1.95 & 4.60 & 19,291 & 21,403 & 1,677 \\
\hline 5 & 中部 & 1.07 & 2.51 & 10,219 & 11,525 & 1,832 \\
\hline 6 & 近畿 & 1.38 & 3.18 & 13,463 & \begin{tabular}{l|l|}
15,026 \\
\end{tabular} & 1,590 \\
\hline 7 & 中国 & 0.89 & 1.98 & 8,204 & $\begin{array}{l}, 669 \\
\end{array}$ & 2,338 \\
\hline 8 & 四国 & 0.59 & 1.30 & 5,601 & 6,380 & 2,080 \\
\hline 9 & 九州 & 1.30 & 2.91 & 12,100 & \begin{tabular}{l|l|}
14,159 \\
\end{tabular} & 2,053 \\
\hline 10 & 沖縄 & 0.12 & 0.25 & 1,121 & 1,302 & 1,427 \\
\hline & 合計 & \begin{tabular}{|l|l|}
10.18 \\
\end{tabular} & 22.01 & 90,401 & 110,256 & 2,101 \\
\hline
\end{tabular}

る次の2点に着眼した実験を実施した.

\section{a) 道路の区間IDテーブルと各機関の地図との関連づけ}

各機関保有の地図によって位置を表現する際の起点と なる参照点の関連づけ方法が異なると, 図-12のように流 通させる道路関連情報（図では渋滞区間を例示）までの 距離が異なってしまう。また，各機関保有の地図で参照 点間のリンク長が異なると, 図-13に示寸懸念が残る.

図-13の $\alpha$ 地図はIDテーブルの延長に対して1.1倍と分 かっているので，参照点からの距離および渋滞長を基準 換算して送信している. また, $\beta$ 地図はIDテーブルの延 長に対して1.2倍と分かっているので，参照点からの距離 および啮滞長を換算して相対的に正しい位置を得ている. こうした送受信が行われないと，送信者の意図する位置 に道路関連情報を重ね合わせられないことが懸念される.

この状況を踏まえ，本研究は，次のことを定めた道路 の区間Iテテーブルと各機関の地図との関連づけの実験を 実施することとした.

・交差点（立体交差，JCTおよびIC部を除く）は，道路 の区間IDテーブルの元データであるDRMのノード点 の位置の定義方法 ${ }^{16} に$ 従う。

・立体交差は，交差する道路の交点を参照点とし，区 間の端点もその位置に設定する.

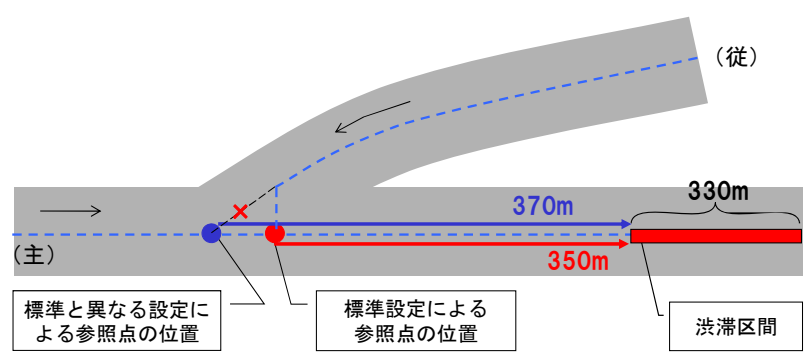

図-12 参照点の違いによる情報交換の矁念事項

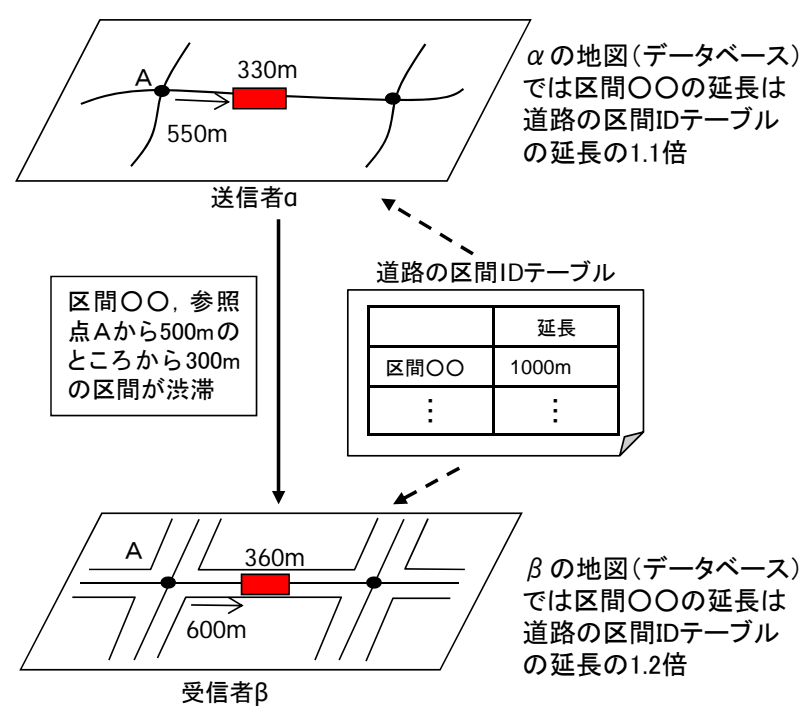

図-13 リンク長の違いによる情報交換の懸念事項 
・JCTおよびICは，各区間の接続路の中心を参照点と し, 参照点間を接続路の1区間とする (図-14参照).

・距離標や道路管理者が定める参照点は，各機関の地 図上の道路中心線の該当する箇所に関連づける.

・県境や市区町村境は，各社の地図上の県境・市区町 村境と道路中心線との交点を参照点とする.

\section{b) 各機関の集計データ (プローブデータ)の比較}

昨今，時々刻々と変化する道路交通状況を把握するた め，官民の各機関で自動車の走行履歴を記憶したプロー ブデータが収集・活用されている ${ }^{19)}$ ，道路の区間ID方式 を用いた多様な道路関連情報の流通には，プローブデー タもひとつのコンテンツとなる. その際，複数の機関で 収集されたプローブデータや異なる地図で算出された旅 行速度を統一した位置表現で地図に重祆合わせることが できると，交通計画，道路整備の効果計測や災害対応な どへの高度活用に繫がると期待される.

集計したプローブデータは, 1台ごとの走行履歴の生デ 一タを収集し，各機関保有の地図に基づいて集計してい る.しかし，各機関保有の地図（道路ネットワーク）で リンクや一条・二条線の扱い方が異なると，図-15の例の ように，集計されたプローブデータの值が異なってしま う。したがって，道路の区間I方式を用いたプローブデ ータの流通に際しては，各機関の地図の交差点内のプロ 一ブデータの扱いなどを踏まえつつ，どの程度の集計デ 一タの精度が確保できるのかを明らかにしておく必要が ある。

本研究は，次のことに着眼した道路の区間I方式によ るプローブデータの交換実験を実施し，同方式に準じて 表現したプローブデータの精度を確認した.

・各社の集計単位で算出したプローブデータを比較す ることが可能かを把握する.

・各社の結果を同一の単位 $(100 \mathrm{~m} \cdot 500 \mathrm{~m}$ 単位 $)$ で集計 した際の区間平均速度の差を把握する。

今回の実験では，表-8の位置およびプローブで構成し たプローブデータを交換する，位置は，特定の位置とそ の距離とで表現する，プローブは，走行した日付，時刻

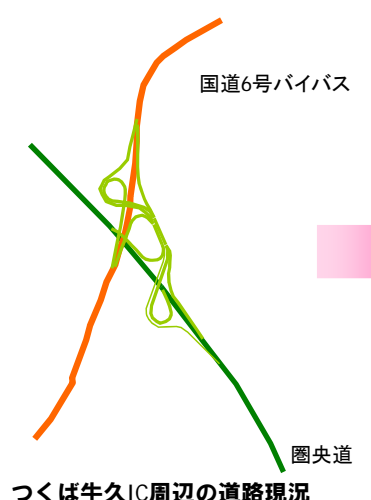

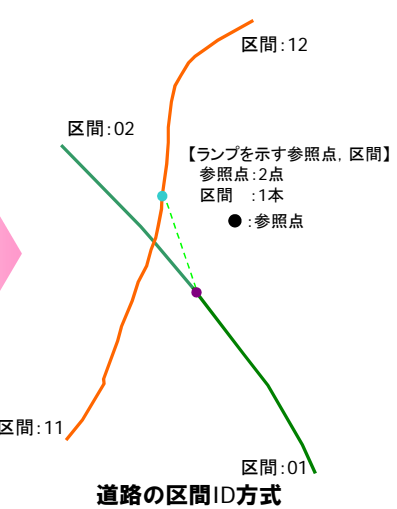

道路の区間ID方式
図-14 ICの参照点・区間の設定例
および区間平均速度とする。

実験内容としては，各機関で集計されたプローブデー タの值が異なることを踏まえ，リンク長と区間平均速度 精度との相関を分析し，データの精度面の信頼性を確認 する．換言すると，どの程度のリンク長であれば，どの 程度の区間平均速度の精度なのかを確認する。

\section{（2）実験デ一タ及び実験手順}

実験の対象区間(利用する道路の区間Iテーブル)は, 土浦市周辺の国道6号および国道408号の約 $18 \mathrm{~km}$ とした。 データの比較には，普通自動車の走行履歴をマップマッ チングしたプローブデータを利用した. 本実験は, 地図 調製やカーナビ地図を扱っている民間企業3社の協力の下， 各社の地図上に道路の区間IDテーブルを関連づけた後, 同じプローブデータを用いて各社が保持するリンク単位 で集計したデータを道路の区間ID方式で表現して比較分 析した.

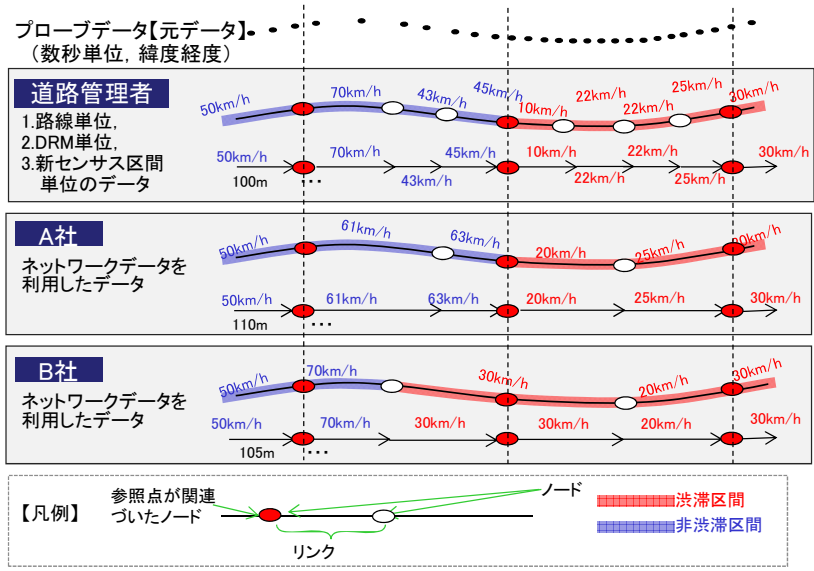

図-15 異なる地図を用いたプローブデータの表現例

表-8 実験で交換するプローブデータの構成

\begin{tabular}{|c|c|c|c|}
\hline & \multicolumn{2}{|r|}{ 項目名 } & 記入内容 \\
\hline & \multicolumn{2}{|c|}{ バージョン } & $\begin{array}{l}\text { 道路の区間IDテーブルのバージョン } \\
\text { 本実験では「2203」で固定 } \\
\end{array}$ \\
\hline & \multicolumn{2}{|c|}{ コンテンツ名 } & 本実験では「プローブデータ」で固定 \\
\hline & \multicolumn{2}{|c|}{ 区間ID } & 本実験の対象区間のIDを記入 \\
\hline & \multicolumn{2}{|c|}{ 参照点ID } & 本実験の対象区間のIDを記入 \\
\hline \multirow{5}{*}{$\begin{array}{l}\text { 位 } \\
\text { 置 }\end{array}$} & \multicolumn{2}{|c|}{ 区間の距離 } & 自社地図での当該路線IDの距離 (単位: $\mathrm{m}$ ) \\
\hline & \multicolumn{2}{|c|}{ 方向フラグ } & $\begin{array}{l}1=\text { =間の起点から終点へ } \\
2=\text { =間の終点から起点へ }\end{array}$ \\
\hline & \multirow{3}{*}{ 距 } & \begin{tabular}{|l|} 
相対距離 \\
(区間始点 $)$ \\
\end{tabular} & 自社地図での相対距離 (整数)（単位:m） \\
\hline & & 区間距離 & 自社地図での区間距離 (整数)（単位:m） \\
\hline & & \begin{tabular}{|l|} 
区間の端点から \\
参照点までの距離
\end{tabular} & $\begin{array}{l}\text { 自社地図での区間の端点から参照点までの距 } \\
\end{array}$ \\
\hline \multirow{3}{*}{$\begin{array}{l}\text { プ } \\
\square \\
1 \\
フ \text { ブ }\end{array}$} & \multicolumn{2}{|c|}{ 日付 } & 区間始点を通過した日付をyyyymmddで表記 \\
\hline & \multicolumn{2}{|c|}{ 時刻 } & 区間始点を通過した時刻をhhmmssで表記 \\
\hline & \multicolumn{2}{|c|}{ 区間平均速度 } & $\begin{array}{l}\text { 時速kmを整数で記載 } \\
\text { (整数, 小数点以下四捨五入) }\end{array}$ \\
\hline
\end{tabular}




\section{(3) 実験結果と考察}

a) 道路の区間IDテーブルと各社の地図との関連づけ

道路の区間IDテーブルと各社の地図との関連づけには, 各社共通して道路の区間IDテーブルに収録のDRMノード やリンクの属性を利用していた．また，18km程度の道路 の区間Iテーブルと自社地図との関連づけに1〜 6日程度 の作業時間を要した．今回の実験では各社とも手作業で 関連づけていたが，実運用の際にはツールなどの開発に より，省力化を図ることが可能との回答を得た.

自社地図の道路中心線，県境および市区町村境の形状 の差により，自社地図に設定した参照点の位置が最大で 数十mの差があることが明らかとなった. この原因とし ては，地図に含まれる誤差が挙げられる，地図調製企業 （カーナビ地図を扱う企業含む）の保有地図は，縮尺 1/25,000のエリアも含まれており, その場合, 約 $30 \mathrm{~m} の$ 誤 差が含まれる. また, 県境および市区町村境は, 道路中 心線と県境や市区町村境との交点に参照点を設定したが, 道路の区間IDテーブルで示寸位置と各機関の地図上で関 連づけた位置との差が異なる結果となっていた。この原 因は, 図-16に示寸ような市区町村境が地図によって異な ることが考えられる.

以上の結果から，道路の区間IDテーブルと各社の地図 との関連づけは技術的に対応できるが，異なる地図間で 情報交換する際は，その情報の用途を踏まえて各地図の 持つ誤差が認識できる情報交換規約を設けるなどの措置 を講ずることが望ましい，実験結果から得た今後の課題 として, 参照点（とくに，道路管理者が用いている距離 標）の位置を各社で差異なく容易に関連づける方策を検

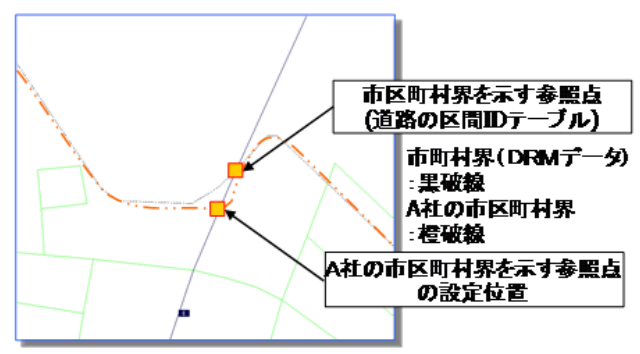

図-16 参照点の異なる例

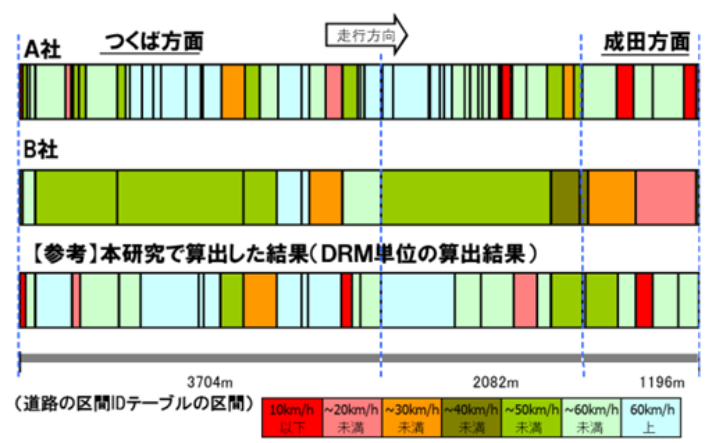

図-17 各社独自の集計単位の比較（国道408号）
討する必要がある，具体的には，関連づける際の参考值 として，道路の区間IDテーブルの提供にあわせて，一意 に判断可能な地物と参照点との位置関係を示す情報の提 供や道路基盤地図情報 ${ }^{20)}$ などの大縮尺地図（縮尺1/500， 水平誤差 $0.25 \mathrm{~m})$ から算出した緯度経度を提供する方策が 考えられる.

道路の区間 $\mathrm{ID}$ 方式の普及を促進するには，同方式を活 用して流通させる道路関連情報（コンテンツ）を具体化 する必要がある，また，各道路関連情報の表現方法や精 度に関する実験を実施し, 上記の誤差の扱いも含めた「道 路の区間ID方式を利用したコンテンツ流通仕様」などの 規程を設けることが一方策としてあげられる.

\section{b) 各社の集計データ（プローブデータ）の比較}

道路の区間ID方式は，区間の長さを固定せず，参照点 からの距離を利用して任意の区間距離を表現できる。こ の特性を活かした実験として, 本研究は自社独自の集計 単位の算出結果を提供いただけた2社の資料を用いて, 次 の比較分析を実施した.

·各社独自の集計単位の比較

・ 区間単位で集計した結果の比較

- 任意距離 $(100 \mathrm{~m} \cdot 500 \mathrm{~m}$ 単位) の集計結果の比較

図-17は国道408号, 図-18は国道6号の各社独自のプロ ーブデータの集計単位の比較結果を示している.いずれ も速度低下の傾向は一致しているが，区間の端点となっ ている交差点周辺では速度差が見られた。

図-19は国道408号, 図-20は国道6号の道路の区間IDテー ブルの区間単位で集約した比較結果を示している.
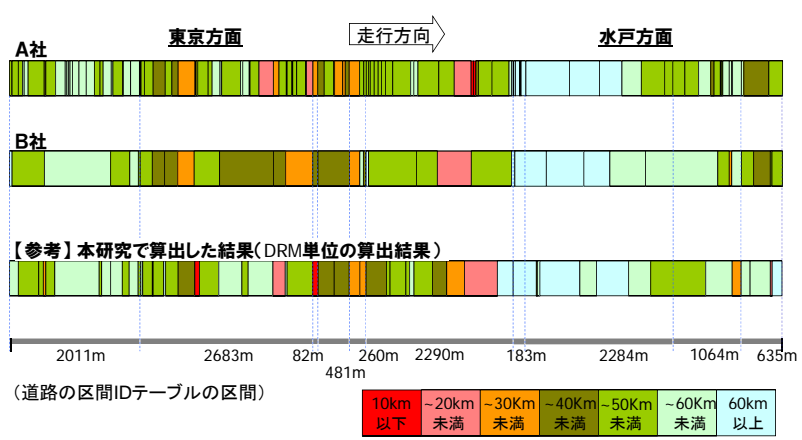

図-18各社独自の集計単位の比較（国道6号）

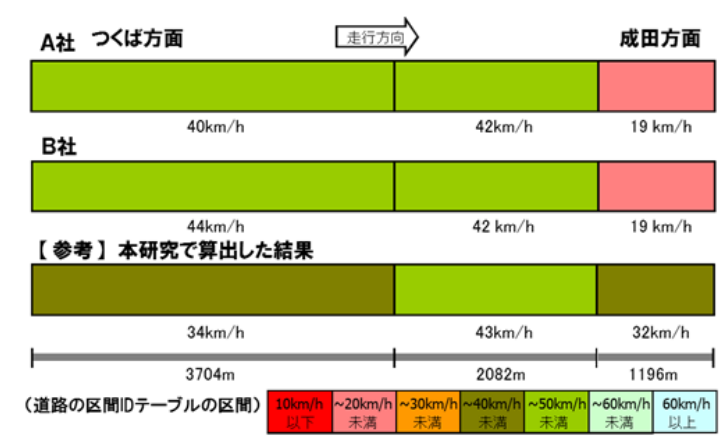

図-19 区間単位で集計した結果の比較（国道408号) 


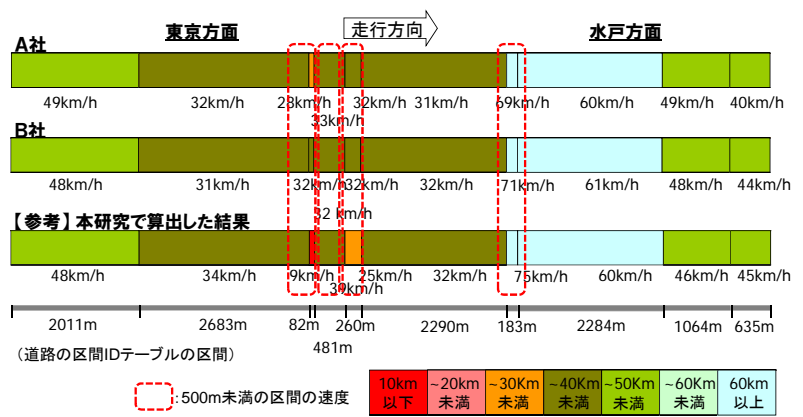

図-20 区間単位で集計した結果の比較（国道6号）

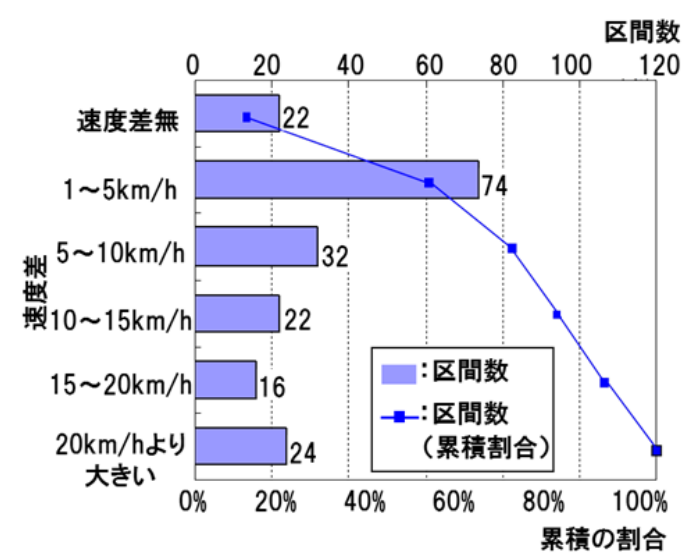

図-21 100m単位の区間平均速度の差

図-19を見ると，約10km/hの平均速度の差が生じている. この原因を分析したところ，次の2点を得た．1点目は， 前項の実験結果でも示した各社地図で参照点の設置方法 (交差点中心の定義) が異なることである. 2点目は，ク リーニング処理による久損值の発生や旅行速度の算出方 法による相違（信号の待ち時間の取扱いなど）である. 後者のプローブデータを用いた旅行速度算出における特 性や留意点は既往研究21-22)でも指摘されている. 図-20で は，区間のリンク長が500m未満の4区間では平均 $12 \mathrm{~km} / \mathrm{h}$ の差，500m以上の9区間では平均 $3 \mathrm{~km} / \mathrm{h} の$ 区間平均速度の 差が見られた（図中の赤枠）。

図-21および図-22は，DRMリンク単位の算出結果から 任意距離として100m単位および500m単位に集計した区間 平均速度を真值（検証データ）とし，各社独自の集計単 位の算出結果から $100 \mathrm{~m}$ 単位・500m単位に集計した区間平 均速度速度と比較した結果を示している. 各図から $100 \mathrm{~m}$ 単位の場合は約5割，500m単位の場合は約7割が区間平均 速度差 $5 \mathrm{~km} / \mathrm{h}$ 以内に含まれることがわかった. また, $100 \mathrm{~m}$ 単位では区間平均速度差が20km/h以上になる区間が24区 間あったが，500m単位では1区間であった。区間平均速 度に差が生じるのは，様々な要因が重なり断定すること は難しいが，今回の実験結果に基づくと，前項の各機関 の地図と道路の区間IDテーブルとの関連づけによる差, 集計単位の設定の差およびプローブデータの計算方法の 違いが大きな要因と想定される.

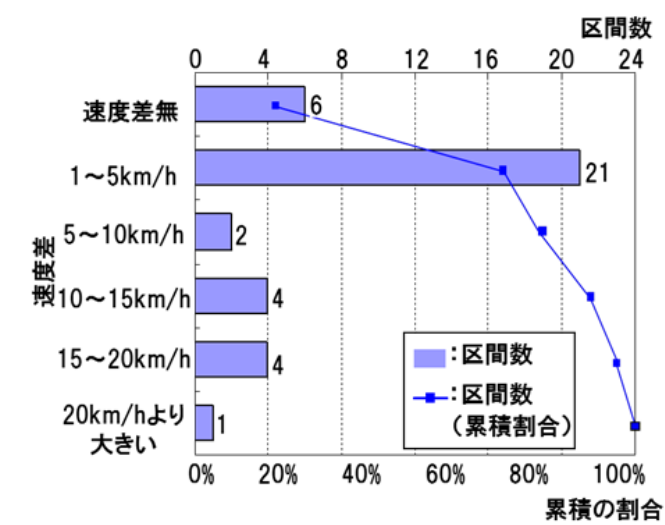

図-22 500m単位の区間平均速度の差

以上の結果から，異なる地図を用いてプローブデータ から算出された旅行速度を道路の区間ID方式による統一 した位置表現で比較すると，集計単位の区間を長くする ほど旅行速度の差が小さい傾向であることがわかった。 ただし，今回の実験で利用したプローブデータは車両1 台分であったため, 今後の課題としては, 複数台分のプ ローブデータを用いて実験を実施し，プローブデータを 道路の区間ID方式で表現した際に速度差が生じやすい地 点（交差点など）などの把握があげられる．また，道路 交通センサス，交通計画，道路整備効果計測や災害対応 などで活用できる精度を確保しているのかも併せて検証 し，活用シーンに即したプローブデータの流通仕様を作 成していくことがあげられる.

\section{6. 結論}

(1) 本研究の成果

本研究は，道路の区間と参照点とを用いて相対的に道 路上の位置を特定し，異なる地図間でも送信者の意図す る位置表現で道路関連情報が交換できる道路の区間 $\mathrm{ID}$ 方 式を確立し，実証実験を実施して有用性を確認した。

第2章および第3章では，道路の区間ID方式への要件を 再定義した上で，各要件を満足する方法論を考案し，仕 様を具体化した。 そして, 道路交通センサスの路線を対 象にした約20万kmの道路区間I テーブルを作成した。

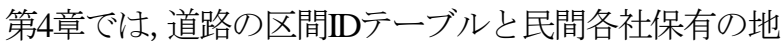
図とを関連づけた後，プローブデータの集計結果を比較 した，その結果，道路の区間Iテテーブルと民間各社の保 有地図との関連づけは可能であるが，異なる地図間で情 報交換する際は，各地図の持つ誤差が認識できる情報交 換規約を設けるなどの措置を講ずる必要があることを確 認した．また，異なる地図を用いてプローブデータから 算出された旅行速度を道路の区間ID方式による位置表現 で比較すると，集計単位の区間を長くするほど旅行速度 の差が小さい傾向が見られることを確認した. 


\section{(2) 今後の展開}

本研究により，道路の区間IDテーブルと各機関保有の 地図とで差異なく容易に関連づける方策，プローブデー タを道路の区間ID方式で表現した際に速度差が生じやす い地点（交差点など）の把握および同方式を活用した流 通仕様の作成などの今後の課題を明らかにした．本研究 は, 今後も引き続き,これらの課題への解決策を検討し, 道路の区間I方式を国内外の標準となるように活動する.

謝辞 : 本研究は, 官民で構成した「位置参照方式検討会」 で議論を重ねてまとめた成果であり，同検討会の委員に は貴重なご意見・示唆や実証実験の協力を賜った．中部 地方整備局道路部上坂克巳部長, 宮崎河川国道事務所大 脇鉄也所長，長崎河川国道事務所門間俊幸所長，広島国 道事務所松本治男副所長には道路の区間ID方式の参照点 および区間の定義に関する貴重なご意見を賜った.ここ に記して感謝の意を表する。

\section{参考文献}

1）地理空間情報活用推進研究会 : 地理空間情報（GIS） を巡るビジネス, 市場規模, 地理空間情報活用推進研 究会（第 2 回）配付資料， 2008.

2）電子情報技術産業協会: 統計資料（民生用電子機器国 内出荷統計および移動電話国内出荷統計），2011.

3）国土交通省国土技術政策総合研究所：次世代デジタル 道路地図のあり方に関する研究, 国土技術政策総合研 究所資料，ISSN1346-7328，No.372， 2007.

4) International Organization for Standardization : Intelligent transport systems (ITS)-Location referencing for geographic databases-Part 1: General requirements and conceptual model, ISO 17572-1, 2008.

5) International Organization for Standardization : Intelligent transport systems (ITS) —Location referencing for geographic databases-Part 2: Pre-coded location references (pre-coded profile), ISO 17572-2, 2008.

6) International Organization for Standardization : Intelligent transport systems (ITS) - Location referencing for geographic databases-Part 3: Dynamic location references (dynamic profile), ISO 17572-3, 2008.

7) International Organization for Standardization : Geographic information-Linear referencing, ISO 19148, 2012.
8) Scarponcini, P. : Generalized model for linear referencing in transportation, Geoinfomatica, Vol. 6, No. 1, pp. 35-55, 2002.

9) Duckeck, R., Hendriks, T., Hessling, M., Otto, H., Pfeiffer, H. and Wevers, K. : Specification of the AGORA Location Referencing Method, presentation for ERTICO-AGORA, 2003.

10) Hendriks, T., Wevers, K., Pfeiffer, H. and Hessling, M. : AGORA-C specification- Specification of the AGORA-C on-the-fly location referencing method, Presentation for Mobile.Info, 2005.

11) Wevers, K. and Hendriks, T. : AGORA-C on-the-fly location referencing, Proceedings of TRB 2006 Annual Meeting, 2006.

12) Adachi, S. : Development of Coordinate-based. Dynamic Location Referencing Method, Proceedings of 11th ITS world Congress, 2006.

13) Schneebauer, C. and Wartenberg, M. : On-The-Fly Location Referencing Methods for Establishing Traffic Information Services, IEEE A\&E Systems Magazine, pp.14-21, 2007.

14) 山川隆夫, 関本義秀, 石田稔, 柳田聡 : 路線番号など を用いた道路の共通位置参照方式に関する検討, 第 27 回交通工学研究発表会論文集，pp.125-128， 2007.

15) Fuse, T., Endo, K., Arimura, S. and Ochiai, O.: Verification of a New Location Referencing Method, Proceedings of 16th ITS World Congress, 2009.

16) 日本デジタル道路地図協会 : デジタル道路地図データ ベース作成作業マニュアル第 100226 版, 2010.

17）日本規格協会 : 地域メッシュコード, JISX0410, 2002.

18）上坂克巳, 間間俊幸, 橋本浩良, 松本俊輔, 大脇鉄也 : 道路交通調査の新たな展開〜 5 年に 1 度から 365 日 24 時間へ〜，士木計画学研究・講演集，Vol.43， 2010.

19）門間俊幸, 橋本浩良, 松本俊輔, 水木智英, 上坂克巳 : プローブデータ活用と道路交通分析の新たな展開, 土 木技術資料，Vol.53，No.10，pp.14-17， 2011.

20) 遠藤和重, 金澤文彦 : セカンドステージ ITS によるス マートなモビリティの形成に関する研究，建設マネジ メント技術，2010年 8 月号, pp.30-36, 2010.

21) Federal Highway Administration : Private Sector Data for Performance Management Final Report, FHWA-HOP-11029, 2011.

22) 李強, 姜美蘭, 森川高行 : 幹線道路リンクごとに集計 されたプローブカー旅行時間データの特徵分析, 土木 計画学研究・講演集, Vol.32, 2005. 


\section{LOCATION REFERENCING METHOD FOR DISTRIBUTION FOR VARIOUS ROAD RERATED DATA}

\section{Ryuichi IMAI, Satoru NAKAJO, Mitsuaki MATSUYAMA, Koichi SHIGETAKA, Minoru ISHIDA and Takahiko HAMADA}

Because of the progress of informatization the accumulation and exchange of electronic information for roads has increased. Much of road information links positioning with map information. If we could share and cross organizations such information we could upgrade the existing information and create new services. One of the existing problems are the differentials in the maps coordinate data. This could cause position error between the sender and the receiver. Also there is the problem of the aging of the existing road network information and ID tagging.

Our research will demonstrate a location referencing method named "Road Section Referencing with Road Section Identification Data set (RSIDs)" by using reference points within road sections. This paper will explain the definition, the result of creating the authority table all over the major road in Japan, and the result of the data exchanging experiments. 